\title{
TEACHING ENGLISH VOCABULARYBY USING GUESSING GAME TOTHE FIFTH GRADE STUDENTS 117 PALEMBANG
}

\author{
Sri Yuliani \\ Sriyulianihamzah@yahoo.co.id \\ Faculty of Teacher Training and Education, Muhammadiyah University of Palembang
}

\begin{abstract}
The aim of this study was to find out whether it was effective or not to teach English vocabulary by using guessing game to the fifth grade students of Elementary school 117 Palembang. The population of this study was all the students of elementary school 117 Palembang in the academic year of 2016/2017 with the total number of students was 205 . Meanwhile, the sample of the study was taken convenience sampling method. There were 40 students who were classified as the control group and 40 students who were classified as experimental group. The method of the study was experimental method, and the type of experimental method is quasi experimental. In collecting the data, the researcher gave a test. In analyzing the data, the researcher used student's individual score, conversion score range, and t-test. Based on findings, the mean of students' pretest in experimental group was 72.125 , while the mean of students' posttest in control group was 65.450. Furthermore, the result of independent sample t-test indicated that value of t-obtained was 5.046 at significant level $\mathrm{p}>0.005$ for two-tailed test t-table is 1.9908 . It is showed that t-obtained was higher than t-table, so it was concluded that Ho was rejected and Ha was accepted. It is clear that teaching English vocabulary by using guessing game was effective to the fifth grade students of Elementary school 117 Palembang.

Key words: teaching, English vocabulary, guessing game
\end{abstract}

\section{INTRODUCTION}

English is an International language which is used throughout the world. In Indonesia, English is one of the foreign languages taught in the formal education. It is taught from elementary school to college, even in kindergarten, they have started to study English. As we know, at the Elementary school English as an extra subject and it can be taught in the class once in a week for one hour. Teaching of English to younger learners (elementary school) is very important because it will serve as the main foundation for students to learn to higher level. Singleton (in Brumfit, 1997) says that there are a number of the reasons for teaching English at primary level, they are (p.6).

The need to expose children from an early age so that they grew up tolerant and sympathetic to others.

The need to link communication understanding of view concept.

The advantages of stating with early second language instruction so that later teacher can use the language as a medium of teaching.

Another reason why English has got to be taught to Elementary school have the capacity for learning and acquiring a new language English easier. The students of Elementary school should be able to read, listen, write, and speak. Therefore, the students must need vocabulary. So, 
teaching vocabulary in Elementary school is focused on vocabulary because, vocabulary cannot be separated from other elements in teaching and learning process in English language skills. So that,

\section{Vocabulary influence the students' ability in studying English.}

Vocabulary is a subject at school about the words which studied by the students. Vocabulary is one of linguistics features which influences the communicate competence. Learning vocabulary is the most important for understanding knowing of things, action, and concepts. Without knowing vocabulary, students are unable to grasp the idea. Meanwhile, teaching vocabulary is important to make students are able to communicate by using language that learnt. They have to master English vocabulary before mastering English. They will be not able to express themselves clearly if they don't master vocabulary before. Mc Catty and O'Dell (2001) state that English has a very large vocabulary, which adds greatly to our opportunities to express the meaning in different style, (p.16).

Based on the writer's observation at elementary school 117 Palembang, she found that most students were not serious in learning English, especially in learning English vocabulary. They felt bored of listening to their teacher's explanation. In addition, they also did not know and understand the meaning of the words. As the result, the students could not learn English vocabulary well. By seeing condition above, the teacher must be able to choose a good technique in teaching and learning vocabulary that make the students are happy and interested in learning. According to Suyanto (2007), in selecting the techniques of teaching in classroom, a teacher should always remember that young learners like to learn by doing. One of the most interesting technique in teaching and learning vocabulary is guessing game.

According to Hadvield,(1984), game is an activity with rules, goals, and element sof fun.. Next, Game is an activity with rules Games was applied to make the students easy to keep new words in their mind. The students looked happy when they played game. They like to move their bodies, such as playing games and singing songs. Furthermore, games also help the students to improve their motivation in learning English. As the result, they will be more serious to learn. Guessing game is one of some games in teaching technique. Guessing game is a game in which the object is to guess some kind of information, such as a word, a title, and an object. It is clear that guessing game will improve students' motivation in learning English and improve their vocabulary.

Based on the background above, the problem of the study was formulated in the following question: "is it effective to teach English vocabulary by using guessing game to the fifth grade students of elementary school 117 Palembang? Furthermore, the objective of this study was to find out whether it is effective or not to teach English vocabulary by using guessing game to the fifth grade students of elementary school 117 Palembang.

\section{LITERATURE REVIEW}

\section{Definition of Teaching}

Teaching is the profession of a teacher. According to Slameto (2010), teaching is guidance of learning.. Next, Brown (2007) states that teaching is guiding and facilitating learning, enabling the students to learn, set condition for learning (p.8). The statement means that the teachers' functions are as facilitator, guide, motivator, and manager. First, as a facilitator, a teacher 
provided the facilities such as circumstances, equipment, aids that make learners were possible to learn easier. Second, as a guide, a teacher showed or helped the learners to learn how to do and understand something. Third, as a motivator, a teacher stimulates the interest of the learners. Finally, as a manager, a teacher arranges information and environment for students to learn. It is clear that teaching is an activity between teacher and students that the teacher can give knowledge and guide the students in teaching and learning process so that they are related each other.

\section{Theory of Vocabulary}

According to Oxford Advanced Learner's Dictionary, Vocabulary is all the words that a person knows or uses. Vocabulary is one of the components in language. We can not do anything without vocabulary especially when we want to tell something to other people. Next, Hiebert (2005) "vocabulary is the knowledge of meanings of words (p.3). It is clear. According to Hiebert (2005) vocabulary is the knowledge of meanings of words "(p.3). It is clear that Vocabulary is a part of words which have meaning and as one of an important element in learning English. Without vocabulary the people cannot communicative effectively. Hiebert (2005) also suggests that words come in at least two forms : oral and print. Knowledge of words also comes in at least two forms, receptive that which we can understand or recognize and productive the vocabulary we used when writing and reading. Print vocabulary consists of those words for which the meaning is known when we write and speaking (p.3).

Vocabulary is a part of words which have meaning and as one of an important element in learning English. Without vocabulary the people cannot communicative effectively. Hiebert (2005) also suggest that words come in at least two forms : oral and print. Knowledge of words also comes in at least two forms, receptive that which we can understand or recognize and productive the vocabulary we used when writing and reading. Print vocabulary consists of those words for which the meaning is known when we write and speaking (p.3).

\section{Teaching English Vocabulary}

To learn foreign language, especially English, it cannot be separated from learning vocabulary. Vocabulary supports all the words to express opinion, ideas, and feeling in communication.

Vocabulary is one of linguistic component that must be involved in learning English because the knowledge of vocabulary plays an important role in mastering the four language skills. In teaching vocabulary, a teacher needs materials, exercises, and strategies. Bordon (cited in Suara, 2014) states as follows:

Material motivating the students

Classes presented in a variety ways.

Several strategy for unlocking the meaning of words,

Ways of showing students how to remember what they have learned.

\section{Game}

Paul (2003) states that game plays as a central role in a child-centered lesson and make it possible for children to fully immerse themselves in learning. Next, Nilwan (2010) defines game as structure in learning. Game is characterizing of what players do. Furthermore, Wright (2006) states that game is an activity which is entertaining, engaging and activity in which the learners play and usually interact with others (p.1). It is clear that game can improve students learning 
motivation. Games are kinds of learning activities which the students' attention is focused mainly on wordsand gamesencourage learners to recall words and prefebably at speed.

Some Techniques of Giving Games

The game makes use of a variety of techniques. Variety of techniques is important in language teaching. Techniques used include Guessing, Matching, Role play, and Simulation.

\section{Guessing Game}

Guessing Game are similar variant on principle. The player with the information deliberately with holds it, while other guesses what it may be.

2. Matching game

Matching game is based on different principle but also involve a transfer of information. The games involve matching identical pairs of cards or picture may be played as while class activity, where players must choose pictures or card from selection to match those by their partner from the same selection or as card game.

3. Role play

Role plays are many games include an element or role play. The players are given the name and some characteristics plays true sense, as the role play element is always subordinate to the game for the purpose of language use.

4. Simulation

Simulation is the imitation in classroom of total situation where the classroom becomes a street, a hotel, a supermarket while practice interaction as shops, tourist officers.

In this study, the writer used guessing game as a technique of teaching English vocabulary in conducting the research to the fifth grade students of elementary school 117 Palembang.

\section{Guessing Game Teaching Technique}

According to Rivers (in Thorbury, 2002), "vocabulary cannot be taught. It can be presented, explained, included in all kinds of activities, and experienced in all manner of associations but it is learned by the individual. As we know, game is an activity with rules, a goal and an element of fun. Teaching vocabulary through game will make the students be easy to memorize the words and the students will also be fun in studying.

Guessing game is one of some games in teaching technique. In addition, Philip (2003) states that the children read a text that is mostly in their first language but has some English words mixed into it. They use the context to guess the meaning of English words. It can be a tool to introduce, review, and reinforce new vocabulary to the students. It can make the students to be more memorizing the words. It is clear that guessing game is a good technique in teaching vocabulary in the class to make the learners or students fun in studying and make them be easy to improve their English vocabulary.

\section{The Advantages of Teaching Vocabulary by Using guessing Games}

The teachers can use guessing games technique because there are many advantages of teaching by using guessing games as described by Morris (1976) They are as follows:

The games promote physical growth and development

The games promote the socialization process

The games are fun for the students like to play them

The games make students enjoyable in learning 
The games develop emotional understanding between one student to another

The games provide language practice in various skills, such as: speaking, writing, reading, and listening (p.2).

\section{Teaching and Learning Vocabulary by Using Guessing Game}

First, the writer gave 20 things in the classroom as the materials to the students. Then, the writer gave some clues related to things in the classroom, for example, a thing that is usually used for writing. Next, the students had to guess what thing is. After the student guessed it correctly, the writer asked the student to write the words at the board. If there was a student who wrote the words incorrectly at the board, so the writer informed the student about the correct words. After that, the writer gave the picture of thing that had been guessed correctly by the student. At last, the student showed the picture to their friends in front of the class.

\section{METHOD}

In this study, the writer used quantitative research. The method used in this study was experimental. The type of experimental group is quasi-experimental. According to Frankel et, al (2012), quasi experimental designs do not include the use of random assignment. Writer who employ these design rely instead on other techniques to control threats to internal validity (p.275). This design provide a pretest to both groups, treatment activities with experimental group only, and a posttest assess the difference between two groups.

In this study, the experimental group was taught vocabulary through guessing games as a treatment, while the control group was taught by using conventional way without guessing games technique. The design as follows:

Pretest Treatment

Experimental group

Control group
Posttest

$\mathrm{O} 1$

$\mathrm{X}$

Where:

O1 : The pretest in experimental group

O2 : The posttest in experimental group

$\mathrm{X}$ : Treatment

O3 : The pretest in control group

O4 : The posttest in control group

\section{Population and Sample}

In this study, Population is all the fifth grade students of elementary school 117 Palembang namely: VA, VB, VC, VD, VE with the total number of 205 students. While, the sample of this study was taken two classes, namely: Class VA who were classified as experimental class, and class VB who were classified as control class with total number of 80 students by using convenience sampling. Convenient sampling is a non-probability sampling technique where subjects are selected because of their convenient accessibility and proximity to the researcher.

\section{Technique of Data Collection}

In collecting the data, the writer gave the test. Data was collected through pretest and posttest. Pretest has been given to the students before giving treatment to see how far the students know 
about vocabulary, and posttest has been given after treatment to find out students' vocabulary improvement. The data collected by giving a test. There are 30 items. The type of test was : 15 items of multiple choice, and 15 items of matching.

\section{Technique of Data Analysis}

In analyzing the data, the writer used:

1. Students' Individual score

Students' individual score can be calculated by using the formula:

$$
X=\frac{R}{T} \times 100
$$

Where : $\mathrm{X}=$ the result of students' individual score

$\mathrm{R}=$ total number of correct answer

$\mathrm{T}=$ total number of items

2. .t-test

Pair sample t-test used to know the difference between the result of students' pretest and posttest in experimental and control group. Next, independent sample t-test was used to know the significant difference between the students' posttest in experimental and in control group.

\section{FINDING AND DISCUSSION}

Finding of the result can be grouped into parts: (1). The result of students' Pretest in Experimental group, (2). The result of students' Posttest in experimental group, (3). The Comparison of students' Pretest in experimental group, (4). The result of student pretest in control group, (5) The result of posttest in control group, (6). The comparison of students' pretest and posttest in control group, and (7). The comparison of students' posttest in experimental and control group.

\section{The result of Students' Pretest in Experimental Group.}

The pre-test was given to know how far the students' vocabulary. In this study was found that the maximum score of the total scores was 82.0 , that was reached by two students and the minimum score was 56.5 also reached by two students, the median was 64.500 , the sum was 2608.0, and the mean was 65.200 .

\section{The Result ofStudents' Posttest in the Experimental Group}

The students' score in the posttest were better than those in the pre-test, the average score was much higher than those reached in the pretest. The result of the post-test in the experimental group showed that maximum score was 84.0, minimum score was 65.0, the median was 71.250, the sum was 2885.0 , and the mean was 72.125 .

\section{The Result of Students' Pretest in Control Group}

The result of pre-test in the control group showed that maximum score was 80.0, minimum score was 52.5, the median was 58.250, the sum was 2411.5 and the mean was 60.288 .

\section{The Result of Students' Posttest in Control Group}

The result of the post-test in the control group showed that the maximum score was 81.0, minimum score was 55.0, the median was 64.000 , the sum was 2618.0 and the mean was 65.450 . 


\section{The Comparison of Pretest and Posttest in Experimental Group}

Based onthe result of the paired sample t-test showed the value of t-obtained was 10.029 at the significant level $\mathrm{p}<0.05$ for two tailed and degree of freedom was 39 , the critical value $t$-table was 2.0227 as showed in the table 1 .

Paired Samples Test

\begin{tabular}{|c|c|c|c|c|c|c|c|c|}
\hline & \multicolumn{5}{|c|}{ Paired Differences } & \multirow[b]{3}{*}{$\mathrm{T}$} & \multirow[b]{3}{*}{$\mathrm{df}$} & \multirow[b]{3}{*}{ Sig. (2-tailed) } \\
\hline & \multirow{2}{*}{$\begin{array}{c}\text { Mea } \\
n\end{array}$} & \multirow{2}{*}{$\begin{array}{l}\text { Std. } \\
\text { Deviati } \\
\text { on }\end{array}$} & \multirow{2}{*}{$\begin{array}{l}\text { Std. } \\
\text { Error } \\
\text { Mean }\end{array}$} & \multicolumn{2}{|c|}{$\begin{array}{c}95 \% \\
\text { Confidence } \\
\text { Interval of the } \\
\text { Difference }\end{array}$} & & & \\
\hline & & & & Lower & Upper & & & \\
\hline $\begin{array}{l}\text { Pai posttest } \\
\text { r } 1 \text { - pretest }\end{array}$ & $\begin{array}{c}6.92 \\
50\end{array}$ & 4.3671 & .6905 & 5.5283 & 8.3217 & 10.029 & 39 & .000 \\
\hline
\end{tabular}

\section{The Comparison of Pretest and Posttest in Control group}

The result of the paired sample t-test showed that the value of t-obtained was 9.977. At the significant level $\mathrm{p}<0.05$ for two tailed and degree of freedom was 39 , the critical value t-table was 2.0227 as illustrated in the table 2 .

Paired Samples Test

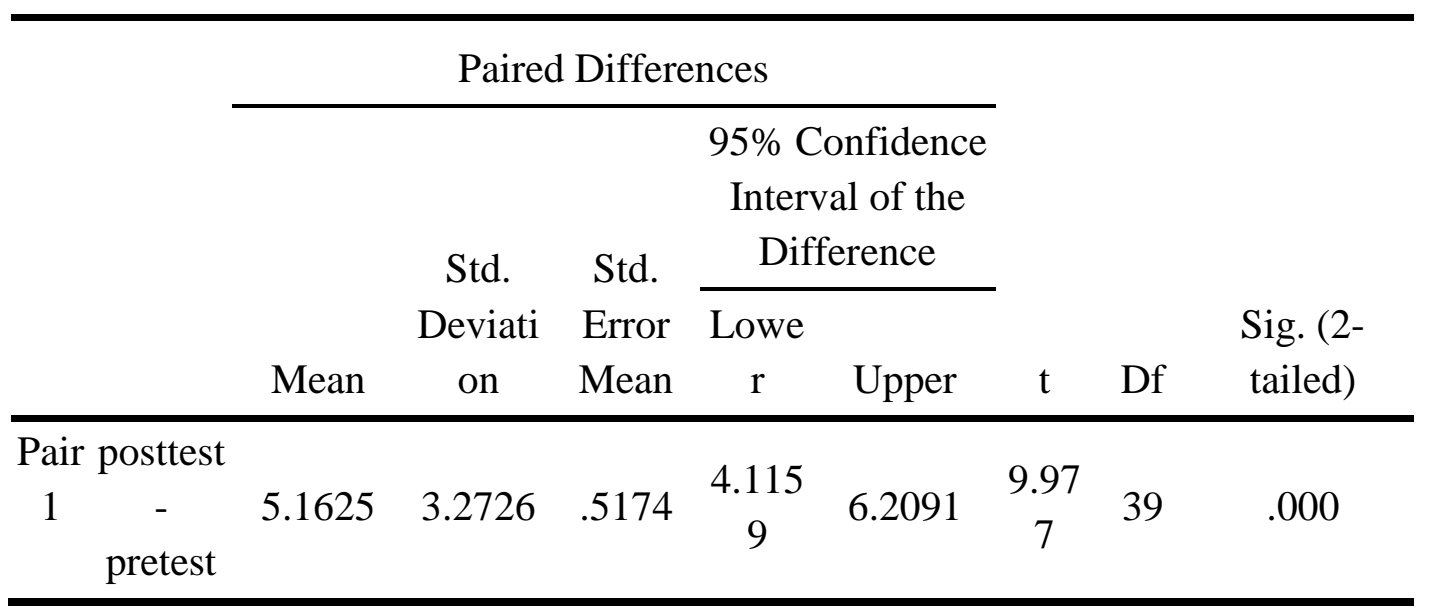

\section{The Comparison of Posttest in Experimental Group and Control Group}

Based on the result of independent sample test showed the value of t-obtained was 5.046, at the significant level p>0.005 for two tailed test and degree of freedom was 78, t-table was 1.9908 as displayed in the table 3 . 
Independent Samples Test

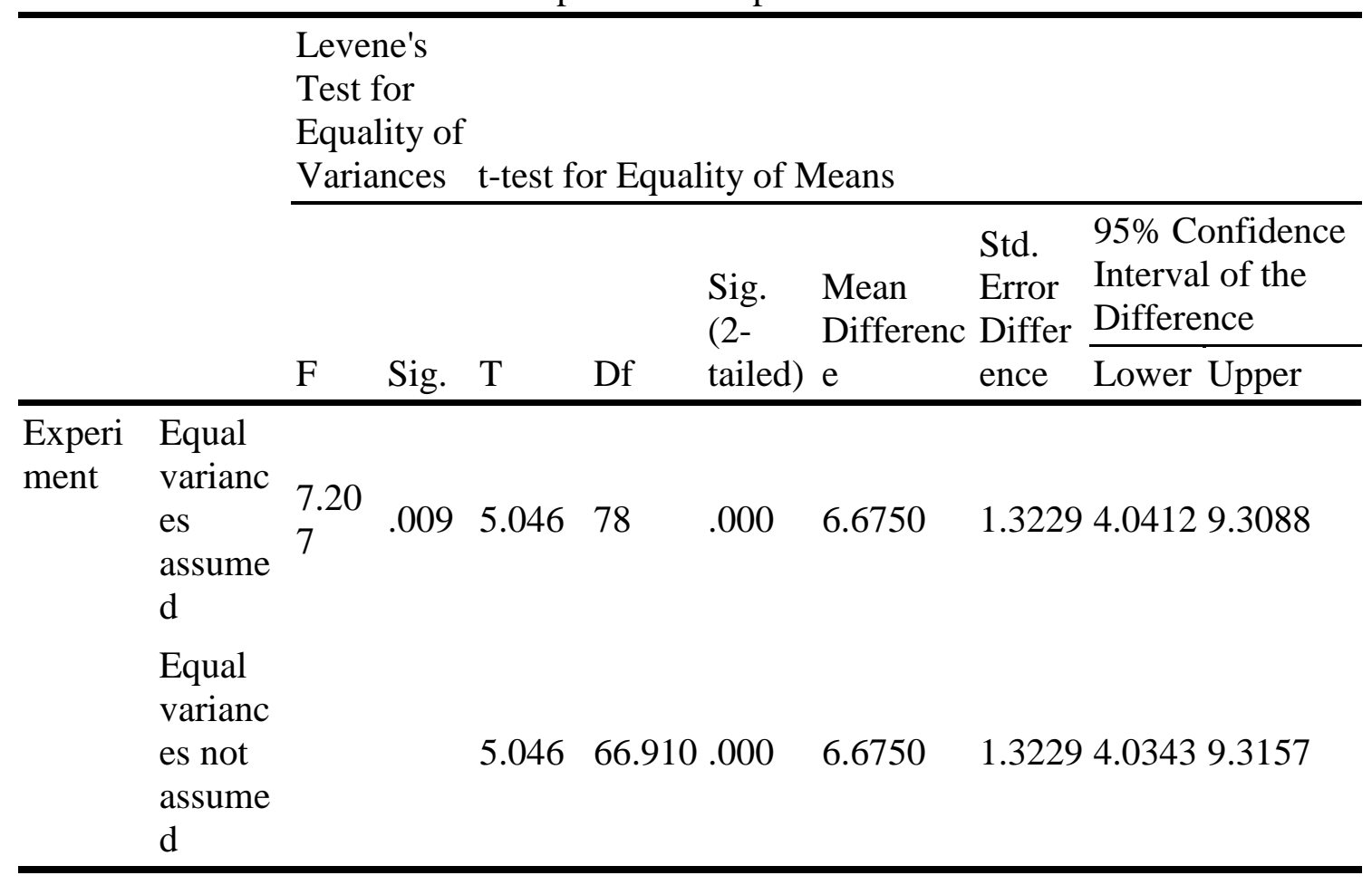

\section{CONCLUSIONS}

Based on the data analysis above, the mean of students' posttest in experimental group was 72.125 and the mean of students' posttest in control group was 65.450. Furthermore, The result of independent sample t-test showed that t-obtained was 5.046 which was higher than t-table 1.9908. Since the value of t-obtained was higher than t-table, so that the null hypothesis was rejected and alternative hypothesis accepted. It can be concluded that there was significant difference between the students who were taught by using guessing games as a technique of teaching and those who were not. It is clear that teaching vocabulary by using guessing game is effective to the fifth grade students of Elementary School 117 Palembang.

\section{SUGGESTIONS}

These suggestions are dedicated to:

1. Teachers of English

The teachers of English are suggested to apply and modify the teaching technique, so the students do not feel bored when teaching learning process and they will be fun and motivated to study English.

2. The students

The students are suggested to learn seriously and actively.

3. Other researchers

Other researchers are suggested to make further research especially concerning on teaching vocabulary that is useful to solve the problems' teaching and learning. 


\section{REFERENCES}

Brown, H.D. (2007). Principle of Learning and Teaching. San francisco University: Longman:

Brumfit, C., Moon \& tongue, R. (1997).Teaching English to Children. From Practice to Principle. Collin English Lnguage Teaching: Longman.

Fraenkel, J.R. Wallen, N.E. (2012).How to Design and Evaluate Research in Education. New York: McGraw-Hill.

Hadvield, Jill. (1984). Elementary Communication Game.A Collection of Game and Activities for Elementary Students of English. Hongkong: Nelson.

Hornby, A.S.. (2010). The oxford advance learner's dictionery (8th Edition). London: Oxford University Press

Hiebert, Elfrieda H and Kamil, Michael L.(2005).Teaching and learning Vocabulary, Bringing Research to Practice. London: Lawrence Erlbaun University Press.

Mc. Catty, Michael \&O’Dell, Felicity. (2001). Test your English Vocabulary in Use, UpperIntermediate. New York. Cambridge Press.

Morris, G.S. Don. (1976). How to Changes the Game Children Play: United States of America: Burgess Publishing Company.

Nilwan, Augustine. (2010). Programming and Game Animation Professional. Jakarta: Gramedia

Paul, D. (2003). Teaching English to Children in Asia. Hongkong: Longman.

Philips, Sarah. (2003). Compiled Material. English for Young Learners. New York: Oxford University Press.

Slameto.(2010). Belajar dan Faktor-Faktor Mempengaruhi. Jakarta: RinekaCipta.

Suara, D.(2014). Improving Students' Vocabulary by using diaryof awimpy kid movie to the tenth grade students at SMA Sriguna Palembang. Unpublished Undergradute Thesis. Palembang: Faculty Teacher Training and Education. University of Muhammadiyah Palembang.

Suyanto, K.E. (2007). English for young Learners. Jakarta: PT.Bumi Aksara.

Thorbury, Scott. (2002). How to Teach Vocbulary. England: Pearson Education Limit.

Wright, Andrew. (2006). Game Language Learning Third edition. The United states of America: Cambridge University Press. 